\title{
Opening Argentina to Public-Private Partnerships: Opportunities and Risks for Government Entities and Private Investors
}

\author{
By Ulrich Schüle*, Franz Liening-Ewert ${ }^{*}$, Daniel Schäffer ${ }^{*}$ \\ \& Edith Zeppenfeld ${ }^{\circ}$
}

Since the presidential elections in November 2015, Argentina's economic system has shifted back to a more neo-liberal paradigm. After more than 15 years of "neodesarrollismo" characterized by large scepticism towards inward FDI, the country opens up to international investment into infrastructure. With a new law adopted in early 2017, Argentina promotes public-private-partnership (PPP) projects. The expectations in Argentina vary from the belief that inward FDI will significantly contribute to the modernization of infrastructure to the fear that PPP projects will surrender the country to the interest of international capital. Even though the government believes that the ambitious National Infrastructure Plan with intended investment of US-\$69bn in transport and energy infrastructure cannot be achieved without PPP projects, a critical analysis of the conditions under which PPP projects may be successfully applied in Argentina, is yet missing. In order to identify such conditions, a triangulation of three research methods was chosen: First, cases in Europe and Latin America were analysed in order to identify key success factors and arrangements correlated with project deficiencies. The focus was on contractual arrangements of risk distribution between stake holders and impediments to cash flow analysis. Second, documentary analysis was applied to examine the regulatory and institutional environment in Argentina. Third, in-depth interviews with 22 experts from Europe and Latin America were conducted. The experts represented the major stake holders in PPP projects: officials from government procurement, lawyers, bank representatives, and managers of project companies and major suppliers. As a result, conditions for a successful application of the PPP concept in Argentina's road and underground railway infrastructure as well as in integrated waste management systems were derived. The research was carried out in the framework of a bi-national Master program in International Business run by the Hochschule Mainz (Germany) and UCES, Buenos Aires.

Keywords: Argentina, FDI, infrastructure, multiple case study, Public-Private-Partnership $(P P P)$, risk allocation

\footnotetext{
*Professor, Hochschule Mainz - University of Applied Sciences, Germany.

†Master Graduate, Hochschule Mainz - University of Applied Sciences, Germany and Universidad de Ciencias Empresariales y Sociales (UCES), Buenos Aires, Argentina.

^ Master Graduate, Hochschule Mainz - University of Applied Sciences, Germany and Universidad de Ciencias Empresariales y Sociales (UCES), Buenos Aires, Argentina.

Master Graduate, Hochschule Mainz - University of Applied Sciences, Germany and Universidad de Ciencias Empresariales y Sociales (UCES), Buenos Aires, Argentina.
} 


\section{Introduction}

After more than 15 years of scepticism towards inward FDI, Argentina's economic system shifted back to a more neo-liberal paradigm. The new government, in office since end of 2015 , opens up the country to international investment into infrastructure.

As Argentina invested around 2\% of GDP into infrastructure between 2008 and 2013, a figure clearly below South America's average (The Economist Intelligence Unit 2017: 18), the investment backlog is obvious so that the government intends to increase the annual expenditure for infrastructure to $6 \%$ of GDP (Delgado 2016). However, with an already high budget deficit, Argentina urgently needs private domestic and foreign capital for achieving this figure. Therefore, the government aims at increasing inward FDI as a means of modernizing Argentina's transportation and energy infrastructure. Moreover, investment in a more efficient and environment-friendly waste disposal management is needed. In particular, investment is needed in order to improve recycling activities (Schejtman and Irurita 2012).

As a vehicle to funnel national and international private investment into public infrastructure, Argentina adopted a new law (Ley 27328) on public-private partnership (PPP) projects in early 2017.

Unfortunately, there is no commonly used definition of PPP. The expression "has become an extremely heterogeneous concept" (Kwame-Sundaram et al. 2016: 3). In practice, the definition "varies depending on the degree of ownership of assets and capital expenditure by the private partners" (ibid.). In the context of this paper, PPP agreements "refer to arrangements under which the private sector supplies infrastructure assets and infrastructure-based services that traditionally have been provided by the government. PPPs are used for a wide range of economic and social infrastructure projects, but they are mainly used to build and operate roads, bridges and tunnels, light rail networks, airports and air traffic control systems, prisons, water and sanitation plants, hospitals, schools, and public buildings" (IMF 2006: 1). However, in the context of this study, concession contracts and outsourcing contracts are not seen as PPP.

Even though the government in Buenos Aires believes that the ambitious National Infrastructure Plan cannot be achieved without incoming FDI in form of PPP projects, a critical analysis of the conditions under which PPP projects may be successfully applied in Argentina, is yet missing.

By analysing case studies on PPP projects in Europe and Latin America, examining the regulatory and institutional environment in Argentina, and interviewing 22 experts from Europe and Latin America, the authors identify some of these conditions. 


\section{Conceptual Framework}

\section{PPP Characteristics}

PPP models may be classified in three different ways. The first approach characterises PPPs according to their institutional arrangement, differentiating between PPPs that establish a project company described as Special Purpose Vehicle (SPV), and PPPs that consist of purely contractual agreements. The second approach is to classify PPPs by the different phases of the project's life cycle (Design, Construct, Operate, Maintain). The third approach typifies them according to certain functions such as Design, Built, Finance, Operate, Maintain, Own, Transfer, Lease, Develop, and Buy. Hence, PPP models may vary from Design-Built-Operate (DBO), Design-Build-Finance-Operate-Maintain (DBFOM), Build-Operate-Transfer (BOT), Build-Operate-Own (BOO) to Build-OwnOperate- Transfer (BOOT) models. Thus, a wide spectrum of PPP arrangements allows to adapt to project-specific characteristics. Institutional designs typically put a Special Purpose Vehicle (SPV) in the core of the arrangements (figure 1).

Figure 1. Typical "Non-Recourse" PPP Arrangement

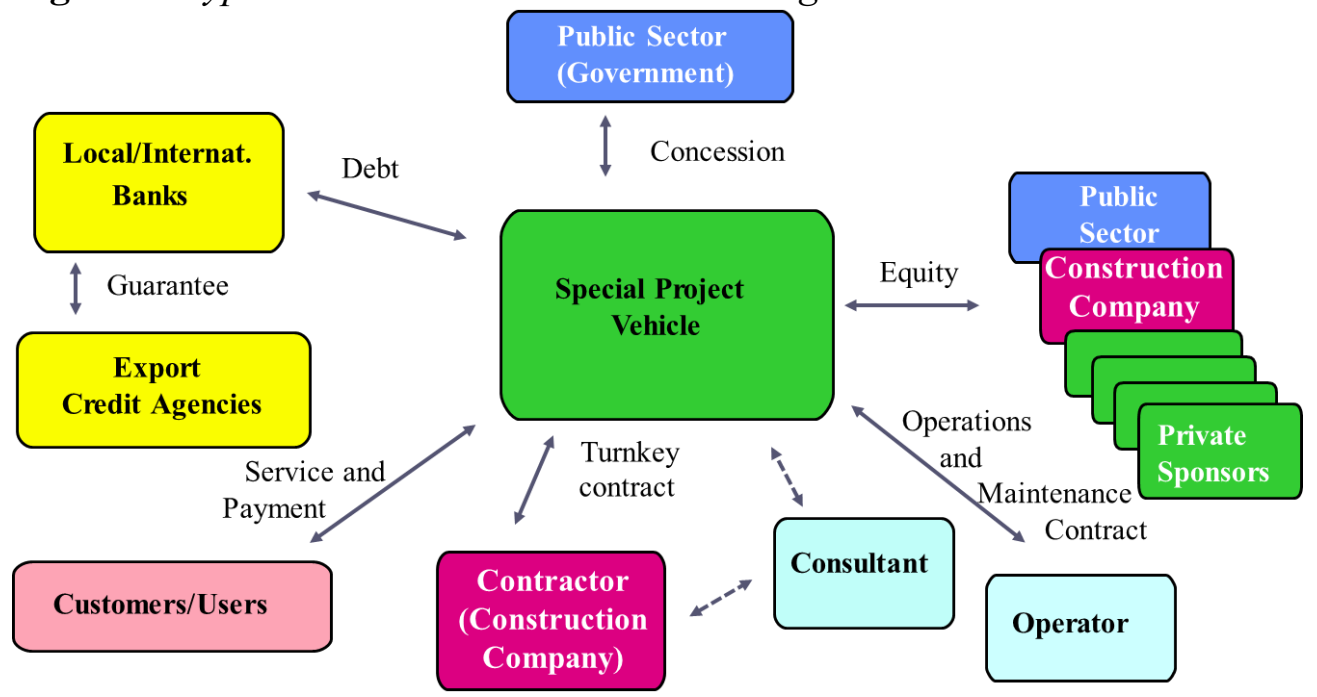

Source: Author.

The construction company (contractor) not only builds the infrastructure complex (for example a motorway) but also invests into the legal owner of the infrastructure, the SPV. Additional equity holders are often government agencies and private investors. In most PPPs, the larger part of capital is provided in form of loans by local and international banks, the latter typically requiring guarantees issued by export credit agencies. As the construction company is not only the seller of the construction service but also partly owner of the principal (SPV), inspection and quality control should be transferred to a private consulting company. This reduces the inherent conflict of interests. The project is operated by a subsidiary of the construction company or an independent operator. Operations 
are based on a concession agreement with which the government assigns the right of operations to the SPV.

Deviations from this standard model are common; reasons for deviations are manifold, but mostly related to the issue of assigning risks appropriately to different stakeholders. In non-recourse arrangements, the investors' liability is restricted to the invested equity whereas full-recourse arrangements make sponsors liable with their complete balance sheet work. Thus, full-recourse arrangements would work without SPVs. In some cases, investors' finance PPP projects with their own resources and later, after construction is completed, issue project bonds to the financial markets (World Bank 2018a).

\section{Risk Allocation}

Mandri-Perrot (2010) describes fair risk allocation as one of four fundamental success factors for PPPs, besides government commitment, a well-prepared PPP model and tender process, and an appropriate regulatory and legal framework. Grimsey and Lewis (2007) point out that risk allocation is the core issue of PPP. Ford, Damnjanovic and Johnson (2015) state that achieving "a balanced and fair allocation of risk between the public and the private partners is critical to project success. If too much risk is borne by the private partner the cost becomes higher than necessary and the public agency may be forced to take premature ownership from a failed developer/operator; if too little is borne by the private partner public funds are wasted" (p. 120).

Principle-Agent Theory may serve as conceptual background for the analysis of risk allocation. The public sector as the principal engages the private sector as agent. The contracts are signed in an environment of asymmetric information and high degrees of uncertainties. Likewise, the contract partners are highly influenced by third parties' interest. Therefore, explicit and rational risk allocation is needed to avoid moral hazard and adverse selection (Oudot 2005). Adverse selection implies that one of the parties conceals information in order to benefit from the information advantage. Moral hazard occurs as the result of one party's action creating risk knowing that the other party will incur the costs. For example, private partners may calculate with unrealistic low costs in the bidding process, referred to as "aggressive bidding", if the public sector assumes the risk of cost overrun.

Firmenich (2014) points out that risk allocation occurs at two levels. The first level is characterised by the risk transfer from the public client to the SPV as representative of the private consortium. At the second level, risks are transferred from the SPV to the consortium members, in particular to the contractor and the operator. This risk transfer is usually conducted with a back-to-back contractual arrangement. However, if the risk recipient fails completely, the responsibilities will fall back to the original risk sender.

Risk allocation takes place before and after the conclusion of the contract. In the first phase, feasibility and risk evaluation are done by public entities in rather qualitative forms. In the next phase, the public entity assesses the project risks based on the quantity of potential losses and the probability of occurrence. In this phase, the decision between conventional public investment and PPP is made. 
Rational governments opt for PPP only if the assumed higher efficiency of private entities overcompensates the high transaction costs of such projects. The capability of successfully carrying out such risk evaluations depends on previous experience with such processes. In case of a lack of experience, governments may better outsource this activity.

The core phase of selecting private partners and negotiating the risk allocation takes place during the tender process. It is crucial that the public institution shares all information. Otherwise, all disadvantages of asymmetric information may occur. It is also recommendable to require evidence from private bidders that they dispose of enough resources to handle the risks if they materialise.

After the conclusion of the contracts, continuous monitoring of the risks over the project's entire lifecycle is essential. If unforeseen and new risks occur, a renegotiation of risk allocation is necessary. According to Guasch et el. (2014), around $78 \%$ of transport infrastructure PPP projects in Latin America had to be renegotiated within the first three years. However, it could also be shown that with growing experience countries were able to improve re-negotiation practices.

According to Li et al. (2002), risks can be classified and may occur at the macro, meso, and the micro level. Macro risks range from changes in legislation and the regulatory framework, often combined with a change in government, social unrest, force majeure, and economic instability leading to unforeseeable changes in interest rates, inflation, and foreign exchange. Risks at the meso level are those related to the nature of the project, like design errors, delays and cost overruns during the construction phase, malfunction in operations and maintenance, and, in particular, the forecast of customers/users. Micro level risks are for example contractual risks providing loopholes for opportunistic behaviour, anticipated contract termination, lack of a party's dedication, and conflicts of interest.

The most common risk lies in an inadequate forecast of demand, for instance an overoptimistic forecast of cars using a PPP's highway. Projects' cash flows heavily depend on future revenue. As demand for infrastructure may be altered by many factors which are not under the control of project management and government, projects are heavily vulnerable if the future demand is estimated too optimistically. In addition, project forecasts in public transportation and waste collection must consider potential free-rider and shirking effects. Therefore, the matter of cash flow analysis and forecast belongs to the core issues of PPP planning (Turley and Semple 2013).

\section{Cash Flow Analysis}

Whereas traditional cost-benefit analysis of public infrastructure focuses on monetizing external effects and the social return on investment (Boardman et. al. 2018), private investors, in particular those investing equity into the SPV, emphasise the Internal Rate of Return (IRR). The IRR depends on the size of the initial investment into SPE equity, the dividends earned throughout the life cycle of the project, and the SPE's residual value (Yescombe 2007). 
The required Equity IRR is composed of the risk-free interest rate and the project-specific risk premium which may vary between the different project phases. In the construction phase, anticipated delays and cost overruns mainly determine the risk premium; in the operation phases, it is rather influenced by increasing uncertainties concerning the predictability of user numbers and revenues. The larger the second effect the more likely private investors may wish to transfer this risk to the government.

In addition to the required Equity IRR, project sponsors need to calculate the cost of debt. As SPVs are typically financed with debt ratios of $80 \%$ and more, the cost of debt plays a dominant role in the cash flow analysis. The Annual Debt Service Cover Ratio as the relation between net operating profits and debt service is commonly used for calculating the required minimum revenues. Other common ratios used for analysing whether the projected cash flow is sufficient to pay the debt service are the Loan Life Cover Ratio and Project Life Cover Ratio (Vinter et al. 2013).

All of these financial ratios have one characteristic in common: Future operating profits - and this means revenues and costs - must be discounted in order to compute net present values. The longer the time horizon and the less stable the country's macroeconomic environment, the more difficult is the cash flow forecast. This is particular true for unpredictable inflation rates. Possible solutions may consist of price indexation and the use of foreign currencies.

\section{Lenders' Risks}

As the SPV's equity basis is rather small and infrastructure assets cannot be confiscated in case of bankruptcy, so that SPVs do not provide sufficient collateral, also lenders rely on the forecasted cash-flow.

Thus, international banks may be prone to transfer the risk of the project's default to the public sector. A standard tool used in the construction phase is guarantees issued by public export credit agencies in the contractor's country. Thus, a German company involved in the construction of a highway in Argentina may apply for the public export credit insurance of the German Euler-Hermes agency. The latter then covers the default risk of German banks lending to the SPV.

Moreover, lenders may insist on full-recourse project structures or require guarantees from the government in the SPV's country. Private financial institutions may also prefer projects in which international development banks and the World Bank Group, in the case of PPP projects most probably the IFC, is involved (Verdouw et al. 2015).

\section{PPP Projects in Argentina}

Even though Argentina was one of the Latin American countries that initiated private co-financing of infrastructure projects in the early 1990s, the majority of these projects seem to be pure concession contracts or failed in the wake of the country's financial crisis of 2001. The post-crisis period under the Kirchner 
governments was then characterized by scepticism towards inward FDI and private participation in financing public infrastructure. The overall investment climate declined and practically impeded international private investment in new projects (Schüle 2015). In complete contrast to the last 15 years, the new Macri government, in office since end of 2015, tries to funnel national and international private investment into public infrastructure. In 2017, the new law (Ley 27328) on PPP was passed at the national level and province-level regulations on public procurement adapted. A sub-secretary for PPP was established in the Ministry of Finance, 60 projects with a volume of USD 26bn defined (Presidencia de la Nación 2017), and workshops in cooperation with the World Bank organized (Subsecretaría de Participación Público Privada 2018). In early 2018, the InterAmerican Development Bank approved a USD 500m investment guarantee facility for PPP projects in Argentina (La Nación 2018).

\section{Methodology}

This study is a first approach to analyse conditions under which PPP projects may be successfully applied in Argentina. It concentrates on projects in road and underground rail transportation, additionally transferring the results to waste collection in Greater Buenos Aires. A triangulation of three research methods was chosen.

\section{Multiple Case Study}

First, cases in Europe and Latin America were analysed in order to identify key success factors and contract arrangements correlated with project deficiencies. The focus was on contractual arrangements of risk distribution between stake holders and impediments to cash flow analysis. The cases were selected from the sectors road and underground transportation. As basic precondition, the selected cases had to be well-documented by the project consortia and independent researchers. Moreover, they should be characterised by different forms of contractual arrangements and risk allocation:

- The Herrentunnel Lübeck in Germany is part of a federal highway connecting the city of Lübeck with Travemünde. The tunnel was built to replace a former bascule bridge. The tender was initiated in 1997, construction started in 2001 and operations in 2005. The basic design of the PPP contract is a BOT model. The SPV's cash inflow mainly stems from toll revenues.

- A8 Augsburg-Munich (Germany) is a 53km part of a motorway serving as principal traffic route in Southern Germany with high relevance for European transit. The project consisted of expanding the existing motorway to six lanes while traffic with up to 100,000 vehicles per day continued. Since 2010, the 6-lane-motorway has been run by a SPV paid in form of "shadow tolls" based on actual traffic volume. 
- Autopistas Armería-Manzanillo and Ecatepec-Pirámides (Mexico), one of them close to Mexico City, one of them in the state of Colima, are classical toll roads owned by the Tribasa Group. The group established a SPV in form of two subsidiaries and later refinanced the investment via bonds in the U.S. capital market.

- The Ruta 5 in Chile is one of the country's principal transport axes. The section Los Vilos-La Serena is $229 \mathrm{~km}$ long. The tender was initiated in 1996, the four-lane road opened in 2002.

- London Underground entered into three PPP projects with the private consortia Metronet and Tube Lines. In 2007, only four years after the project start, Metronet declared insolvency, the company's responsibilities were transferred back into public ownership. The PPP with Tube Lines was prematurely terminated in 2010: Since then, London Underground has been purely publicly run again.

- Lima Línea 2 is Peru's largest PPP agreement, signed as a DBFOM project between the Ministry of Transport and Communication and an international private consortium in 2014. Although the project is still too young to be entirely evaluated, it serves as an example for metro projects in Latin America.

\section{Documentary Analysis}

Second, documentary analysis was applied to examine the regulatory and institutional environment in Argentina. As the adaptations of province regulations during the year 2017 did not create deviations from the national law but only facilitate the application of national law, analysis was restricted to Law 27328. In addition, the legal frameworks of Germany, Mexico, Peru, and Chile were studied. Moreover, project companies' balance sheets - if available - were analysed.

\section{In-Depth-Interviews}

Third, in-depth interviews with 22 experts from Europe and Latin America were conducted. The experts represented the major stake holders in PPP projects: government procurement officials, lawyers, bank representatives, and managers of project companies and major suppliers. Five different interview guides were elaborated focusing on the following expertise:

- Experts of Argentina's political, economic and juridical system

- Lawyers involved in the design and wording of the PPP law 27328

- Experts involved in the design and administration of PPP projects

- Experts of the underground system in Buenos Aires

- Experts in the waste management system of greater Buenos Aires.

The last category of interviews aimed at identifying possibilities for transferring the results to the sector of waste management. 


\section{Findings}

Case studies as well as interviews confirm the importance of risk allocation and realistic cash flow forecasts. Whereas in the analysed cases nearly all macro level risks were allocated correctly, misalignments at the meso and micro level proved to be harmful.

\section{Inadequate Risk Allocation}

The failure of the well-documented Metronet PPP (London underground) shows how inadequate risk allocation jeopardises projects' long-term viability. While the risk of adequate traffic forecast was allocated appropriately to the public sector, inadequate risk allocation at meso and micro level caused the project's failure. Main characteristics were cost overruns, the abuse of the SPV to funnel financial means to capital owners, neglected monitoring by lenders, and an inefficient approval process.

\section{$\underline{\text { Cost Overruns and SPV Exploitation }}$}

The rules on cost overruns included a $£ 50 \mathrm{~m}$ materiality threshold in a predefined 7.5-year period. The risks of cost overruns up to this threshold were allocated to the Metronet owners. Any additional costs, if incurred in an economic and efficient manner, were guaranteed by the public. Therefore, as soon as overrun costs exceeded the threshold of $£ 50 \mathrm{~m}$, the SPV and their owners had no incentive to keep cost under control. As a result, the Metronet owners created a value chain system which allowed them to deliberately create cost overruns and, thus, pump financial means from the public. In order to do so, four of the five Metronet owners (figure 2) - also being simultaneously major suppliers to the SPV formed a second SPV called Trans $4 \mathrm{~m}$. Trans $4 \mathrm{~m}$ signed an agreement with Metronet which made it a privileged supplier to Metronet in carrying out station renovation. Even though a back-to-back arrangement would have transferred the risk of overrun costs to Trans $4 \mathrm{~m}$, the agreement seems to have been used for funnelling funds from Metronet to the capital owners. In addition, Bombardier had a de-facto monopoly in supplying trains and signalling systems to Metronet. The contractual arrangement "gave Metronet very little in the way of enforcement levers and Metronet had little opportunity to contract work elsewhere on more reasonable terms" (Hart 2015, p. 279). 
Figure 2. The Metronet Supply Chain Structure

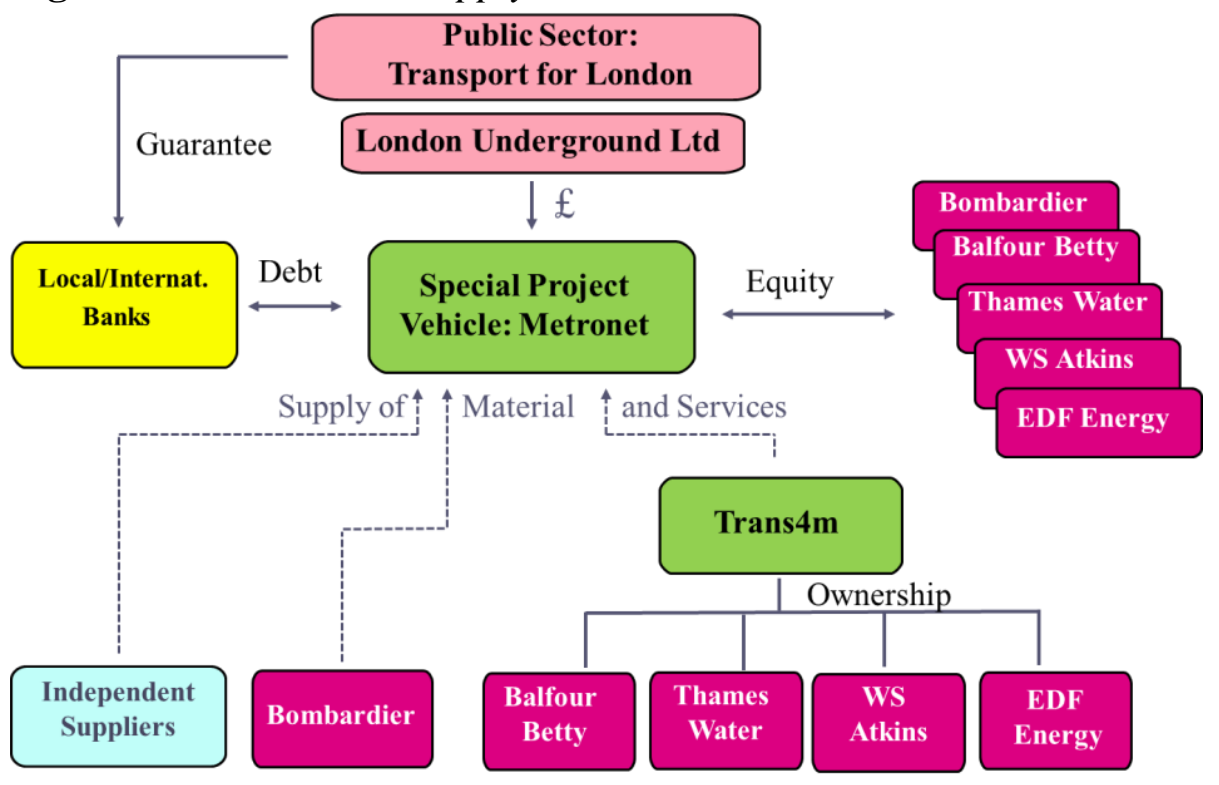

Source: Author.

\section{Neglected Monitoring}

Moreover, bank loans were guaranteed by the government. In the beginning, the amount was set at $90 \%$ of the amount lent to Metronet; later, the guarantee was increased to $95 \%$. Thus, lenders had no incentive to rigorously monitor Metronet's financial behaviour.

\section{$\underline{\text { Inefficient Approval Process }}$}

On the other hand, cost overruns occurred because the effects of delayed construction permits and work inspections were not clearly enough allocated to the project partners. Although the contracts obliged Metronet to submit individual construction plans and committed the public planning entities (London Underground Ltd.) to fast-track approval processes, overlapping authorities and a multitude of decision makers significantly delayed construction works.

\section{Over-Optimistic Cash Flow Forecast}

Ideally, public investment starts with the identification of the need, a careful demand study revealing the demand's willingness to pay, and a thorough estimation of positive as well as negative externalities. However, overestimations of future demand seem to be common. The "optimism bias" may occur in public planning institutions first; but also private companies in search for new projects may tend to be overly optimistic. Whereas Trujillo et al. (2002) argued that privatization - and so PPP models - increase the number of players and, thus, scope for "strategic" behaviour, Flyvberg (2014) claimed that "private investors place their own funds at risk; therefore, funds and banks can be observed to not 
automatically accept at face value the cost and revenue forecasts of project managers and promoters" (p. 16). The cases analyzed in this study as well as the undertaken expert interviews show that this "optimism bias" may occur unless tackled with non-traditional risk allocation.

\section{$\underline{\text { Substitution Processes in Traditional Toll Systems }}$}

The German Herrentunnel may serve as example for projects in which the public planning authorities overestimate future user numbers and transfer the risk to the private PPP partners.

As the tunnel replaced an outdated toll-free bascule bridge, cash flow forecasts were based on a modified extrapolation of already existing traffic. However, planners failed to estimate potential changes in user behaviour. Instead of paying the toll for the new 866-meter-tunnel, many users opted for a $5 \mathrm{~km}$ longer toll-free highway accepting a few minutes more in travelling time.

The project's participants agreed on a BOT scheme, so that a large part of the risks, including the traffic demand risk, was transferred to the SPV. In deviation from figure 1, the SPV was exclusively owned by the two companies in charge of construction ("contractors"). Construction was completed on time in 2005. Since then, the project's success has depended nearly exclusively on the toll revenues collected at a toll station in front of the tunnel.

Based on an estimation of 40,000 vehicles using the tunnel daily, the project's objective was to reach an Equity IRR of approximately $12 \%$.

Upon completion of the works, less than $60 \%$ of the traffic on the former bridge used the tunnel whereas traffic on the nearby toll-free highway increased correspondingly. In 2015, the number of daily traffic was slightly above 16,000. In a nutshell, the project generated enough revenues to pay interest rates on loans but did not produce significant returns to the capital owners. Therefore, toll rates were increased. However, this boosted the incentive to use the toll-free alternative. As a result, the SPV ran losses from year to year, the project needed, and probably still needs, to be re-negotiated. As the main result of a first re-negotiation round, the operation time was extended to 40 instead of the originally agreed 30 years.

Similar substitution processes occurred in Mexican motorway projects. In the 1990s, the Tribasa group had taken over two already existing motorways. From that moment on, road tolls were charged at toll stations which caused an unforeseen decline in user figures - in particular during the Tequila Crisis in 1994/95. It took around six years until traffic figures re-covered to the pre-crisis level. While the crisis decreased traffic volumes in total, users also switched to nearby toll-free roads accepting 20 minutes of additional travelling time in the case of the $47 \mathrm{~km}$-Armería-Manzanillo motorway or 48 minutes in the case of the Ecatepec-Pirámides sector.

\section{$\underline{\text { Shadow Tolls and Availability Models }}$}

Based on the rather disappointing experience with substitution processes, new PPP concepts in road transportation were developed. More recent PPP projects are 
based on availability and road quality. The World Bank's definition of availabilitybased payments includes shadow toll systems (World Bank 2018b). One example for such a model is the German A8 motorway section Augsburg-Munich. The $53 \mathrm{~km}$ section is run by the SPV "autobahnplus A8 GmbH" which itself was formed by a consortium of a Dutch and a Luxembourg-based infrastructure company and two European construction companies. In Germany, trucks pay tolls per km whereas passenger vehicles use motorways toll-free. ${ }^{1}$ The truck toll is set by law and collected electronically based on GPS and GSM transmission. Revenues are transferred to the public budget daily. This system applies to all motorways, regardless of public or private ownership. "autobahnplus A8 GmbH" is remunerated by the government based on the collected truck toll combined with an availability component. So, if excessive repair work reduces the availability of lanes more than expected in the maintenance forecasts, the public authority has the right to reduce the payment of the "shadow toll" and may even charge penalties. Penalties may also be charged if the motorway's quality does not meet the requirements set in the specifications. Therefore, an independent engineering company regularly assesses the motorway's quality. The risk of declining traffic demand is low as toll-free highways are crowded and partly closed for transit truck traffic.

As an alternative model, the SPV may be paid by the government independent from traffic numbers, based exclusively on availability and quality. Thus, the risk of overestimated traffic figures is entirely taken by the government.

Actually, the "Tribasa" PPPs in Mexico combined such an availability and quality component with the traditional toll system. The quality component with its constant revenue flows may have saved the SPV from larger financial stress when traffic figures decreased and stayed low in the 1990s.

\section{$\underline{\text { Subsidies and Minimum Traffic Fee }}$}

Other arrangements use direct subsidies and minimum traffic fees. The latter are calculated on the basis of a guaranteed number of users, regardless of the actual utilization. Thus, they resemble the traditional Take or Pay" agreements in the energy sector.

The analysed case in Chile combines direct subsidies with a minimum traffic guarantee. As quid pro quo, the SPV must transfer $50 \%$ of the revenues to the government if the Equity IRR exceeds 15\% (Elqui Abertis 2015: 10).

\section{Externality and Freerider Problem}

Toll systems work only if non-payers can be excluded from consumption at reasonable cost. Otherwise, freerider problems occur. They are of particular relevance as soon as urban road transportation and waste collection are considered. Excludability in public bus and tram systems can be enforced only with high control costs, for example through video surveillance or access controls. If cities

\footnotetext{
${ }^{1}$ A toll for passenger cars is planned for the future. This would be charged in form of a yearly flat rate for residents and 10-day rates for transit traffic.
} 
wish to attract car users to the public transportation system in order to fight the daily traffic collapse, opportunity costs of enforcing ticket purchasing may be too high. Even more, it would not make sense to exclude non-paying consumers from the use of waste collection systems. Experience in countries where waste collection fees were allocated to the actual quantity of waste is not promising. Substitution in this context means that users may dispose waste illegally, thus transforming public places to waste deposits. Instead of establishing PPP projects in these sectors governments may rather opt for traditional concession models.

The issue of quantity-related remuneration also played a significant role in the waste collection system of Greater Buenos Aires. Concession holders used to be paid according to the quantity of waste collected. In 2005, payment was changed to a system in which the cleanness of the streets became an important determinant of payment. Similar to the models in traffic PPP, frustration about inadequate risk allocation between the public and the private sector led to the new remuneration system in the concession models of waste collection. On the one hand, the public sector negotiated for modifications as the previous quantity-related system had been abused by the concession holders: as quantity was measured in weight, they watered the collected waste in order to increase weight and remuneration. On the other hand, the private concession holders complained that the government had opened waste collection to the informal sector which reduced the quantity they could collect (Clarín 2003).

\section{Inflation and Interest Rate}

Most of the PPP projects include provisions protecting private investors from negative effects of inflation.

The projects in Mexico provide the SPV with the right to increase toll rates without further government approval as soon as the official inflation rate exceeds $5 \%$. In case of lower inflation rates, the SPV may apply for higher toll rates to be approved by the government.

Chile introduced the Unidad de Fomento (UF) in 1967. The UF was first used as a shadow currency to revalue international secured loans and interest rates according to variations in the country's inflation. Nowadays, the UF is commonly used for calculating long-term domestic contracts in real terms and for real estate prices. The UF represents an inflation-adjusted peso value and is calculated on a daily basis.

In the London Metronet case, the Infrastructure Service Charge paid to the SPV had to be increased if the actual inflation rate exceeded the forecasted $2.5 \%$ by at least one percentage point. ${ }^{1}$

Thus, the inflation risk is typically assumed by the public sector. All interview partners pointed out that this is of great importance in Latin America as all countries experienced high and fluctuating rates of inflation in the not so distant past, and nobody would exclude the possibility of future periods with higher inflation rates.

\footnotetext{
${ }^{1}$ In the low-inflation environment of Germany, such an indexation is not common. In particular, availability models exclude such price escalator clauses (Altmüller 2012).
} 
Interest rate risks are related to lending. "Project finance debt tends to be fixed rate. This helps provide a foreseeable, or at least somewhat stable, repayment profile over time to reduce fluctuations in the cost of infrastructure services." (World Bank 2018c). If floating rates are used, hedging is necessary. Two of the interviewed experts pointed out that the related risks are higher in countries with higher inflation rates, such as Argentina.

\section{Currency and Exchange Rate}

Closely related to the inflation risk are currency and exchange rate risks. This risk is particularly virulent if capital infusion and debt are in foreign currency. "The tension between local and foreign currency debt is often a question of balancing fixed rate debt with foreign exchange rate risk" (World Bank 2018c). The interviewed experts point out that the exchange rate risks are to be borne by the government. One expert states that the government in Argentina should collect the tolls in pesos and pay the concession holders in dollars.

\section{Implications for PPP Projects in Argentina}

In the following, the results of our analysis are used to discuss implications for PPP projects in Argentina. We first focus on the macro level, and then later discuss meso and micro level aspects.

\section{Macro Level}

There is a consensus in all expert interviews that the macro level risks of political instability, expropriation, changes in the legal environment, social unrest, inflation, and manipulated exchange rates should be allocated to the public sector. The current government in Argentina follows this idea. Law 27328 on PPP provides the framework for such protection of private investors from changes in the legal environment. However, Argentina's recent history - in particular the expropriation of $\mathrm{YPF}^{1}$, the handling of courts' decisions in the context of the "vulture funds" episode (Guzman and Stiglitz 2016) ${ }^{2}$, and the high number of ICSID cases Argentina lost during the Kirchner governments ${ }^{3}$ - shows that governments not always comply with the "pacta sunt servanda" principle.

\footnotetext{
${ }^{1}$ YPF (Yacimientos Petrolíferos Fiscales) is a vertically integrated Argentine energy company, formerly owned by Repsol (Spain) and re-nationalised in 2012/13.

${ }^{2}$ In 2001, Argentina defaulted on \$132bn in loans during its financial crisis. Argentina re-structured its debt in two rounds of negotiations. $93 \%$ of the creditors accepted the deal. A small minority who had acquired the bonds with huge discounts, refused the deal and were named "holdouts" or "vulture funds". As Argentina first was not able and later not willing to pay the holdouts, a more than decade-long legal dispute kept Argentina isolated from international investment flows. As the government bonds were subject to New York law and the U.S., Argentina had to accept that the dispute was set by U.S. courts.

${ }^{3}$ ICSID is the world's leading institution devoted to international investment dispute settlement initiated and administered by the World Bank.
} 
Moreover, political manipulations of the exchange rate which not only jeopardised Argentina's competitiveness but also stood for "clandestine expropriations" of foreign capital (Archimbal 2015), and obvious misconduct in calculating inflation rates ruined the country's attractiveness for foreign investors (Piazolo 2015). So even if international investors may trust in the new government, PPP contracts with durations of up to 30 years may be at risk in case of future changes in government.

In order to mitigate the risk of national court systems being politically forced to bend the law, contracts relegate law disputes to foreign or international arbitration courts. Argentina's new law allows for such arbitration and states basic conditions for such relegation. However, public discussion in Argentina's context with the "holdouts" and in Germany in the context of the eventually failed TTIP negotiations show that such relegation is increasingly questioned (BBC 2016). Thus, it seems to be crucial that only such arbitration courts are chosen that still seem to be accepted as "neutral" - such as the World Bank's ICSID.

Private investment may reduce the degree of corruption. One simple instrument is that PPP projects require a higher degree of transparency. Capital investors require more documentation of the underlying user and cash flow forecasts than needed in traditional government procurement. Law 27328 includes an own section on anti-corruption rules and states several requirements for documentation. Nevertheless, if Argentina wishes to attract international capital for PPPs, the country needs success in fighting corruption.

Moreover, the new government lifted the exchange control system introduced in 2011. This system impeded the repatriation of profits as the exchange of peso revenues into hard currencies had to be approved by government officials.

In addition, more fiscal and economic stability would facilitate international investment. As it could be shown, low inflation rates and indexation systems which stabilise the real value of PPP revenues are helpful. Even though the government managed to lower inflation significantly from around 40\% in 2016, the current level of more than $20 \%$ is still high and provokes substantial risk premiums to be paid to investors. The recent call for IMF assistance loans and the resulting 50\%-depreciation of the peso in the second and third quarter of 2018 will rather increase than decrease Argentina's macro level risks.

\section{Meso Level}

As long as the macroeconomic environment is characterised by fiscal deficits and significant inflation rates, indexation rules are essential. Concession agreements signed in 2018 stipulate such indexation. For example, the Abertis group, headquartered in Spain, operating motorways in Argentina, received the right to increase motorway tolls twice a year, corresponding to the "Coeficiente de Estabilización de Referencia", a daily calculation of real prices based on the consumer price index (Sanguinetti 2018). This index was initially established in 2002 when in the context of Argentina's financial crisis dollar-denominated credits and debts were transferred into pesos ("pesificación") and the latter devalued dramatically. Later, price indexation was suspended and substituted by mutual 
negotiations between companies and government. The re-established coefficient mechanism seems to be similar to the indexation system in Chile and quite different from the contractual rules applied in Mexico. Interestingly enough, even though all experts stressed the importance of inflation and also exchange rate indexation, this coefficient was not mentioned by any of the interviewed experts.

Besides indexation, PPP contracts must allocate risks related to user and cash flow forecasts appropriately. Here also, Argentina seems to follow the approach of Chile. Article 9k of Law 27328 explicitly refers to minimum revenues which may be guaranteed. The law also opens the possibility of re-negotiating the project duration, a common means of risk reduction for the investors - for example applied in Germany's Herrentunnel and the described Mexican projects. The expert interviews revealed the high risk of over-optimistic user forecasts. They pointed out that the projects need to include the flexibility of prolonging the contract duration in case of lower user numbers. They stated as minimum requirement that the government should provide the SPV with guaranteed minimum revenue, for example in form of subsidies based on a minimum user number. This guaranteed revenue should at least enable the SPV to pay the interest rates on debt (loans). On the other hand, the government should participate in excess revenues created by user numbers higher than projected. However, an increase in demand may also create higher maintenance costs. This aspect must be considered in the negotiations.

Some of the experts critically discussed the imponderables that defy a scientific, reproducible, comprehensive forecast. Thus, they would not apply PPP models with remuneration based on user numbers to innovative projects with unknown and insecure future. In such cases, remuneration models based on availability and quality manage the risk more appropriately. Moreover, projects with significant positive externalities should include a lump sum component in the SPV's remuneration. In general, PPP projects are considered as superior to traditional public projects only if planning, construction and operations resemble each other so that a certain "standard" approach can be applied.

As the above analysis showed, substitution processes between toll roads and toll-free highways jeopardised the projects' success. It is strongly recommended to analyse the possibility of such substitution processes in the planning process. This applies in particular to road construction, bridges and tunnels, where individual traffic may by-pass the toll. However, one might also consider the substitution between different forms of traffic. It needs to be analysed how, for example, new underground lines may deviate or even create traffic. ${ }^{1}$

Substitution and free rider behaviour seem to be significant in case of waste disposal and recycling. In particular, as the principle of excludability for nonpaying customers cannot and should not be applied, PPP projects are unlikely to be successful - even more in the case of Argentina where parts of waste collection are in the hands of the informal economy. Expert interviews revealed the difficulty for governments to meet the different targets of waste collection and transportation, final waste disposal, and recycling. While theoretically PPP models

\footnotetext{
${ }^{1}$ The availability of train systems may significantly increase commuter flows so that road traffic to and from the railway stations rises.
} 
may be used for building and operating recycling plants, the risk that an inefficient waste collection system fails to deliver recyclable solid waste separate from organic residuals is so high that neither the public nor private investors are currently able to cover it. Therefore, other, more innovative, models need to be developed in this sector.

Cash flow forecasts also include costs. The Metronet case clearly shows that excessive government guarantees may cause harm. As project costs are generally more under control of the private sector, the risk of cost overruns should be allocated to the private project partners. Government guarantees should be limited to those cost overruns clearly caused by government actions, such as unjustified delays in project approvals. In addition, the lesson of the Metronet case is that SPVs owned exclusively by the construction and service providers bear the inherent risk of inefficient service contracts between provider and SPV. Therefore, it is recommendable to include additional sponsors as SPV equity owners. As they would monitor the efficiency of the entire supply chain, they form a built-in control of the SPV procurement behaviour. If this is not feasible, government must insist on contractual arrangements with independent engineering and consulting companies. For example, the German A8 project would not be possible without an independent partner who assesses availability and quality of the motorway. The expression "independent" must be stressed. This company must not have any political, cultural or economic relationship to either the public sector or the private investors.

Lenders play an important control function unless their risk is (nearly) completely mitigated by public guarantees. However, increased risk of default taken by the lenders and international credit insurance agencies results in risk premiums. Argentina may have to live with this trade-off. Probably, the participation of World Bank institutions and development banks lowers the risk premium charged by private lenders as they know that governments handle such projects with priority.

\section{Micro Level}

Appropriate risk allocation and cash flow analysis requires experience and experts. All project partners need profound knowledge of the legal, financial, and organizational specificities of PPP projects. The impression gained from analysing cases from different countries and expert interviews is that multinational companies, financial institutions and service providers learned in a 30-year process of "trial and error". In contrast, Argentina's public sector is rather unexperienced in designing PPP projects. This may also apply to local banks and the juridical system. Therefore, it is indispensable that Argentina's public sector acquires knowledge before entering into negotiations. Although Argentina shows substantial progress in forming the necessary competence centre - the already mentioned subsecretary on PPP - the process of institution building and training requires time. Moreover, small-scale projects can be organised with competitive bidding whereas large, complex projects require negotiations, adaptation, and re-negotiations (Estache and Saussier 2014). Therefore, it is recommendable that the project 
partners from Argentina - public as well as private - use the expertise of international and independent experts in form of consultants. Otherwise, the scenario feared by one of the interviewees would come true: "At least in the first two or three projects, Argentina will pay dearly".

Risk allocation at the micro level plays a crucial role, as it basically deals with the fundamental nature of PPP arrangements. Designing an efficient arrangement is a prerequisite for achieving higher value for money than traditional procurement. Micro level risks like premature contract termination or internal conflicts of interest have the potential to ruin entire multibillion projects. Micro level risks should be principally shared between the public and private sector. This is reasonable as both parties rely on the smooth function of the contract throughout the entire projects life cycle to achieve the required rate of return and value for money.

Peru's PPP underground metro project Lima Linea 2 efficiently manages the risk of premature contract termination as well as the risk of lack of dedication by implementing a performance guarantee, named fiel cumplimiento. Here the private sector has to deposit significant amounts that will be paid back over the project's lifecycle. In the event of ruthless premature contract termination or a lack of dedication to perform efficiently, the public authority has the leverage to retain the deposits. On the other hand, the contract regulates that if premature contract termination caused by unreasonable government action, the private sector has to be compensated for all incurred expenses and losses. Furthermore, the performance guarantee deposits also manage the risk of frequent changes in stakeholders and contracting parties. A frequent change in stakeholders, for example replacing the original competent construction company with an incompetent and inefficient one, would substantially jeopardise the performance of the project. Deposits lower that risk. For instance, if the original contractor of the SPV wants to leave the PPP contract, he only might be allowed to do so, if he finds an adequate replacement that also pays the entire amount of the deposit that was borne by the original constructor.

While the investment environment in Argentina is on a rise, interviews show that there is still a considerable low level of investor confidence. Hence, high deposits might discourage investors to engage themselves with long-term PPP contracts. Nevertheless, the success of PPP projects depends critically on the right incentivization. The dedication of all participants to perform in the best possible way is absolutely critical to the project's success. Thus, the responsible government authorities have to assess whether incentives can be set at acceptable risk premiums or not. It is recommendable to switch to other procurement methods if one of the two, incentives or risk premiums, is inefficient.

\section{Conclusions}

This paper analysed conditions for PPP projects in Argentina. As the country was isolated from international capital markets for around 15 years, these conditions differ from other countries. At the macro level, Argentina still suffers 
from investors' confidence in the country's political and economic stability. The need to rebuild trust is obvious. The newest development in Argentina's macroeconomic environment, namely the call for IMF assistance loans and the resulting 50\%-depreciation of the peso in the second and third quarter of 2018, will jeopardise the government's efforts to increase financial markets' confidence in Argentina's capability to keep sovereign risk low. Meso and micro level risks were discussed by analysing PPP cases from Europe and Latin America, evaluating the new legal environment in Argentina, and interviewing 22 experts. The analysis was mainly based on PPP projects in the transportation sector. Thus, more research is needed in other sectors, in particular in the energy and water supply.

Considering the existing asymmetry in experience between Argentina's public sector and international private investors, and the high degree of uncertainty about Argentina's future political, social, and economic stability, our recommendation is that the country starts with PPP arrangements that are rather small-scale and standardised projects. Argentina should, however, restrain from PPP as a model for innovative, highly complex and rather unknown projects. Moreover, it is highly recommendable to include the expertise of the World Bank and the Inter-American Bank in as many projects as possible.

\section{Acknowledgments}

We gratefully acknowledge the financial support of the Centro Universitario Argentino-alemán/Deutsch-argentinisches Hochschulzentrum.

\section{References}

Altmüller P (2012) Entwicklung einer differenzierten Preisgleitklausel für Funktionsbauverträge im Straßenbau [Development of a differentiated price adjustment clause for functional construction contracts in road construction]. Institut für Bauwirtschaft der Universität Kassel.

Archimbal M (2015) Towards the Re-nationalization of Core Industries in Latin America: The Case of Argentina's YPF. In: Schüle U (ed.) International Trade, Finance, and Investment Policies in Argentina, 93-104. Aachen: Shaker.

BBC (2016) TTIP trade talks: German judges oppose new investor courts. Retrieved from https://bbc.in/2RMvlpd.

Boardman AE, Greenberg DH, Vining AR and Weimer DL (2018) Cost-Benefit Analysis. Concepts and Practice. $4^{\text {th }}$ edition, Cambridge: Cambridge University Press.

Clarín (2003) El debate por la recolección de la basura en Buenos Aires [The debate over garbage collection in Buenos Aires]. January $31^{\text {st }}$, Retrieved from https://clar.in/2Dht WTB.

Delgado R (2016 September) (undersecretary of state for public investment) La inversión en infraestructura significa más desarrollo [Investment in infrastructure means more development]. La Nación $11^{\text {th }}$. Retrieved from https://bit.ly/2JWHPYx.

Elqui Abertis (2015) Memoria 2015 [Financial Report 2015]. Retrieved from https://bit. ly/2DimrvN. 
Estache A, Saussier S (2014) Public-Private Partnerships and Efficiency: A Short Assessment. CESifo DICE Report 12(3): 8-13.

Firmenich J (2014) Risk-bearing capacity testing of and within PPP projects. ETH Zürich Conference Paper. Retrieved from https://bit.ly/2DA5EVO.

Flyvbjerg B (2014) What You Should Know About Megaprojects and Why: An Overview. Project Management Journal 45 (2):6-19.

Ford D, Damnjanovic I, Johnson S (2015) Public-private Partnerships: A Study of Risk Allocation Design Envelopes. In Johnston EW (ed), Governance in the Information Era, New York \& Abingdon: Routledge.

Grimsey D, Lewis M (2007) Public-Private-Partnerships: The Worldwide Revolution in Infrastructure Provision and Project Finance. Cheltenham: Edgar Elgar Publishing.

Guasch JL, Benitez D, Portabales I, Flor L (2014) The Renegotiation of PPP Contracts: An Overview of its Recent Evolution in Latin America. International Transport Forum Discussion Papers 2014-18. OECD. Doi=/10.1787/2223439X.

Guzman M, Stiglitz JE (2016) How Hedge Funds Held Argentina for Ransom. New York Times April 4. Retrieved from https://nyti.ms/2zMnosF.

Hart L (2015) Procuring Successful Mega-Projects. How to Establish Major Government Contracts Without Ending up in Court. New York \& Abingdon: Routledge.

IMF (2006) Public-Private Partnerships, Government Guarantees, and Fiscal Risk. Retrieved from https://bit.ly/2OAVHIR.

Kwame-Sundaram J, Chowdhury A, Sharma K, Platz D (2016) Public-Private partnerships and the 2013 Agenda for Sustainable Development: fit for Purpose? United Nations. DESA Working Paper No. 148 (ST/ESA/ 2016/DWP/148).

La Nación (2018) El BID le prestará este año a la Argentina más que a cualquier otro país de la region [Will lend this year to Argentina more than to any other country in the region]. March $22^{\text {nd }}$. Retrieved from https://bit.ly/2B4i7Pc.

Ley 27328. Retrieved from https://bit.ly/2QGPblH.

Li B, Akintoy A, Hardcastle C (2002) Risks and risk treatments in public private partnership projects. In Greenwood D (ed) $18^{\text {th }}$ Annual ARCOM Conference. University of Northumbria. Association of Researchers in Construction Management, 403-14.

Mandri-Perrot C (2010) Private Sector Participation in LRMT Initiatives. In: MandriPerrot C with Menzies J (ed.), Private Sector Participation in Light-Rail-Light-Metro Transit Initiatives. The World Bank PPIAF, 45-87.

Oudot JM (2005). Risk-allocation: Theoretical and empirical evidences. Application to public-private partnerships in the defence sector. In Proceedings of the $9^{\text {th }}$ Annual Conference of the Institutions of Market Exchange, 1-20. Barcelona.

Piazolo, M (2015) Argentina's Macroeconomic Development and its Challenges. In Schüle U (ed.) International Trade, Finance, and Investment Policies in Argentina, 31-50. Aachen: Shaker.

Presidencia de la Nación (2017) Infrastructure Funding: Argentina's PPP Plan. Jefatura de Gabinete de Ministros. Retrieved from https://bit.ly/2B8zyla.

Sanguinetti A (2018) Cambios en las concesiones de las autopistas: los peajes aumentarán dos veces por año [Changes in motorway concessions: tolls will increase twice per year.]. In $w w w . i p r o f e s i o n a l . c o m$, February $20^{\text {th }}$. Retrieved from https://bit.ly/2PvM 9US.

Schejtman L and Irurita N (2012) Diagnóstico sobre la gestión de los residuos sólidos urbanos en municipios de la Argentina [Diagnosis on the management of urban solid waste in municipalities of Argentina]. Retrieved from https://bit.ly/2K4eM5m. 
Schüle U (2015) Argentina's International Trade and Investment Policies - Historical Overview and Current Issues. In Schüle U (ed.) International Trade, Finance, and Investment Policies in Argentina, 13-30. Aachen: Shaker.

Subsecretaría de Participación Público Privada (2018) Segundo Taller sobre Participación Público Privada organizado en conjunto con el Banco Mundial [Second Workshop on Public Private Participation organized in conjunction with the World Bank]. Retrieved from https://bit.ly/2K6Dmmr.

Trujillo L, Quinet E, Estache A (2002) Dealing with Demand Forecasting Games in Transport Privatization. In Transport Policy (9): 325-334.

Turley L and Semple A (2013) Financing Sustainable Public Private Partnerships. International Institute for Sustainable Development. Briefing Note. Winnipeg. Retrieved from https://bit.ly/2TfYevF.

Verdouw W, Uzsoki D, Dominguez Ordonez C (2015) Currency Risk in Project Finance. IISD Discussion Paper. Retrieved from https://bit.ly/2B9hF2e.

Vinter GD, Price G, Lee D (2013) Project Finance, $4^{\text {th }}$ edition. London: Sweet and Maxwell.

World Bank (2018a) PPP Knowledge Lab. Retrieved from https://bit.ly/2PtjEHt.

World Bank (2018b) Toolkit for Public-Private Partnerships in Roads \& Highways. Retrieved from https://bit.ly/2zJkINE.

World Bank (2018c) Risk Allocation, Bankability and Mitigation in Project Financed Transactions. Retrieved from https://bit.ly/2RSAEn9.

Yescombe ER (2007) Public-Private Partnerships Principles of Policy and Finance. Burlington \& Oxford: Elsevier. 
